\title{
Forest fragmentation and selective logging affect the seed survival and recruitment of a relictual conifer
}

\author{
Carlos R. Brocardo ${ }^{\mathrm{a}, \mathrm{b}, *}$, Felipe Pedrosa ${ }^{\mathrm{a}}$, Mauro Galetti ${ }^{\mathrm{a}}$

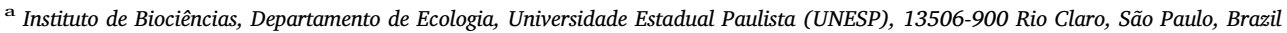 \\ b Neotropical Institute: Research and Conservation, Curitiba, Paraná, Brazil
}

\section{A R T I C L E I N F O}

\section{Keywords:}

Scatter-hoarding

Araucariaceae

Dasyprocta azarae

Cyanocorax chrysops

Sus scrofa

Neotropics

\begin{abstract}
A B S T R A C T
Defaunation, invasive species and forest fragmentation are considered to be the major drivers for the disruption of key ecological processes, particularly those related to plant animal-interactions such as seed dispersal and predation. The disruption of critical phases in the plant life cycle may ultimately have negative impacts on plant recruitment and the survival of plant populations. Here, for the first time we compared the seed removal and recruitment of Araucaria angustifolia, a critically endangered and relictual gymnosperm species, in multiple sites, including continuous and fragmented forest areas in the Brazilian Atlantic subtropical forest. Our sampling included seed removal experiment monitored by camera traps and surveys of $A$. angustifolia recruitment. We found that seed survival and recruitment were related to the density of adult $A$. angustifolia. Therefore the formation of large and dense groves, which is a characteristic of pristine Araucaria moist forests endangered by forest fragmentation and selective logging, may be an attempt to satiate seed predator communities. Additionally, forest fragmentation and the introduction of wild boar decreased seed survival to very low, and forest fragmentation decreased recruitment by fourfold on average. Increase protection and recuperation of Araucaria moist forests and the eradication of the invasive wild boar where possible are necessary measures for increasing seed survival rates and the recruitment of this relictual conifer.
\end{abstract}

\section{Introduction}

Seed survival and seedling recruitment represent a bottleneck in the life cycle of most vascular plants, therefore, for zoochoric species, the presence of dispersers is indispensable to their success (Nathan and Muller-Landau, 2000; Schupp et al., 2010; Galetti et al., 2013; Neuschulz et al., 2016). In fact, both seed dispersal and seed predation have been suggested to regulate plant dominance and thereby maintain forest diversity (Janzen, 1971; Connell, 1978). As a result these ecological interactions play major roles in determining the composition of forests (Kurten et al., 2015).

However, ecosystems suffer globally with human interference altering biological communities and consequently leading to breaks and changes in ecological processes (Sanderson et al., 2002; Tylianakis et al., 2008; Butchart et al., 2010; Estes et al., 2011; Galetti and Dirzo, 2013; Dirzo et al., 2014; Young et al., 2016). Forest fragmentation (Galetti et al., 2006; Cordeiro et al., 2009), the loss of seed dispersers (Wright et al., 2000; Galetti et al., 2006), and changes in the seed predator community (Galetti et al., 2015; Tella et al., 2016b) are among the Anthropocene's effects that may negatively affect plant populations and recruitment dynamics, posing real risks to the future survival of some plant species (Pérez-Méndez et al., 2016). Understanding these impacts on plant recruitment are fundamental to guiding conservation efforts (Kurten, 2013).

In this study, we aimed to investigate the effects of forest fragmentation, selective logging and changes in the animal community on seed predation and the recruitment of Paraná-pine (Araucaria angustifolia), a relictual conifer from a genus originating in the Jurasic period (Kershaw and Wagstaff, 2001). The use of this species as a model is interesting because its presence characterizes a global ecoregion, the Araucaria moist forest. In its absence this ecosystem becomes uncharacterized, a rare case, in which the loss of a single species may change the main attribute of an ecosystem. Additionally, Paraná-pine has been considered a key-stone species for fauna, because it produces a large quantity of resources (seeds) in a period of food scarcity (Autumn-Winter) (Iob and Vieira, 2008), being used by a large number of vertebrate species. However, despite its ecology importance, Araucaria moist forests have experienced strong fragmentation and timber exploitation (Castella and de Britez, 2004; Ribeiro et al., 2009), and the Paraná-pine is Critically Endangered (Thomas, 2013) and has shown recruitment failures in forest fragments (Souza, 2007; Paludo et al., 2016).

\footnotetext{
* Corresponding author at: Instituto de Biociências, Departamento de Ecologia, Universidade Estadual Paulista (UNESP), 13506-900 Rio Claro, São Paulo, Brazil.

E-mail address: carlosbrocardo@hotmail.com (C.R. Brocardo).
} 

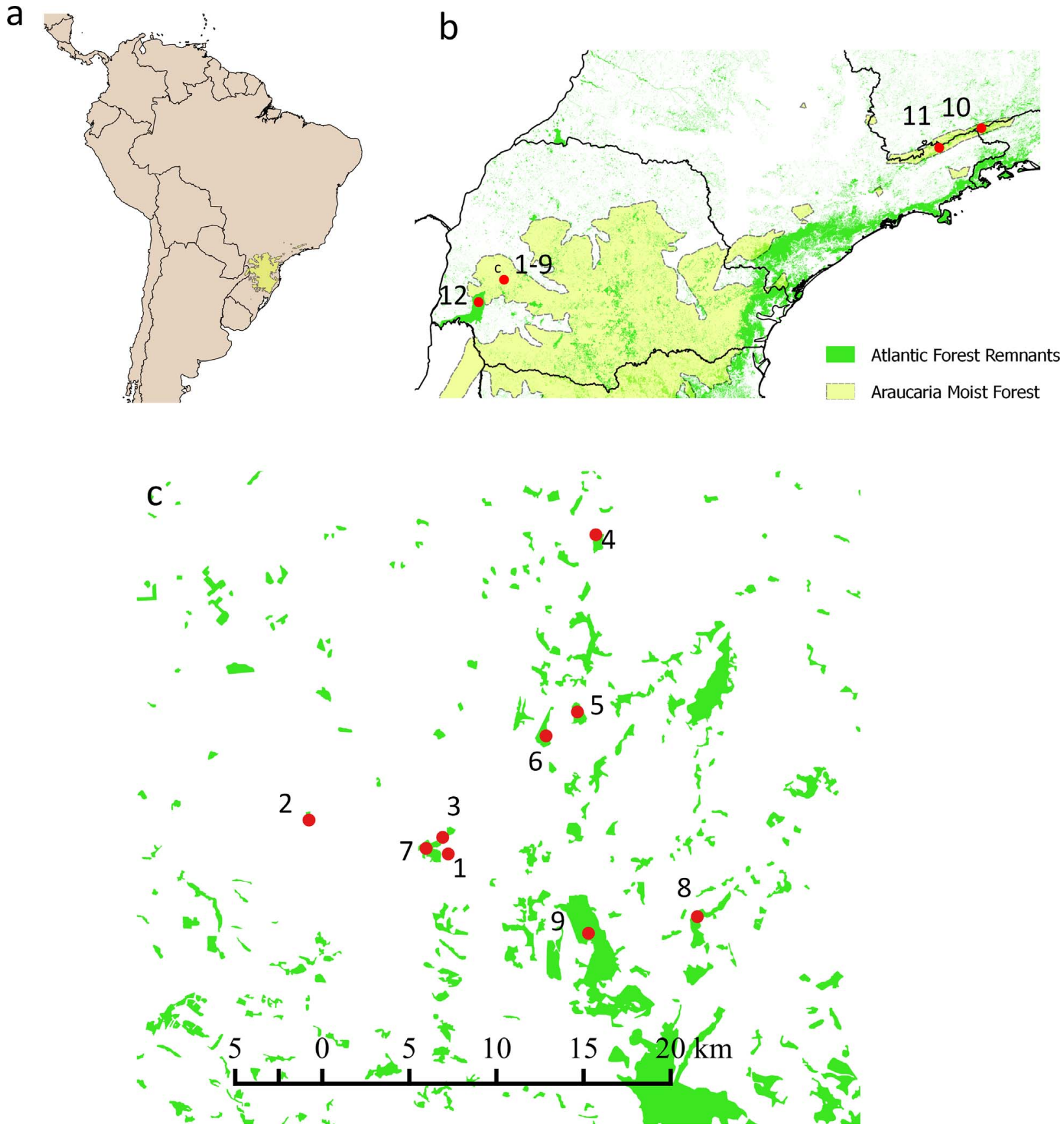

Fig. 1. (a) Araucaria moist forest in South America; (b) sampled sites, and; (c) highlights to 1-8 sampled forest fragments. Site names are presented in Table S1.

Since Paraná-pine seeds rely on animals for dispersal and encounter high rates of seed predation (Iob and Vieira, 2008; Brum et al., 2010; Vieira et al., 2011), we tested the hypotheses that: (I) seed removal will be negatively related to Paraná-pine dominance; (II) high recruitment will be related to high adult female numbers as a result of higher seed abundance (satiation hypothesis); (III) fragmentation will increase seed removal; (IV) in fragments seed removal will be dominated by small rodents due to the release of competition with large mammals; (V) fragments will present low recruitment than control site; (VI) interactions with the largest seed disperser (agouti) will be negatively affected by forest fragmentation; and (VII) buried seeds will have a greater chance of surviving than non-buried seeds, independent of their distance from adult tree, demonstrating the importance of scatter-hoarders for the recruitment of this plant.

\section{Materials and methods}

\subsection{Study areas}

To measure the effects of forest fragmentation and changes in the animal community on seed removal and the recruitment of $A$. angustifolia we studied ten forest fragments and three continuous areas (Fig. 1). Study areas varied from 8 to 181,000 ha (more details about study sites see Supplemental Material). Araucaria moist forest fragments, in general, experienced timber extraction and reduction in seed predator and disperser communities (Brocardo and Cândido-Jr, 2012), while two of our continuous areas represented more intact seed predator community (Iguaçu National Park and Campos do Jordão State Park) (Brocardo et al., 2017), and a third continuous area (Alto- 


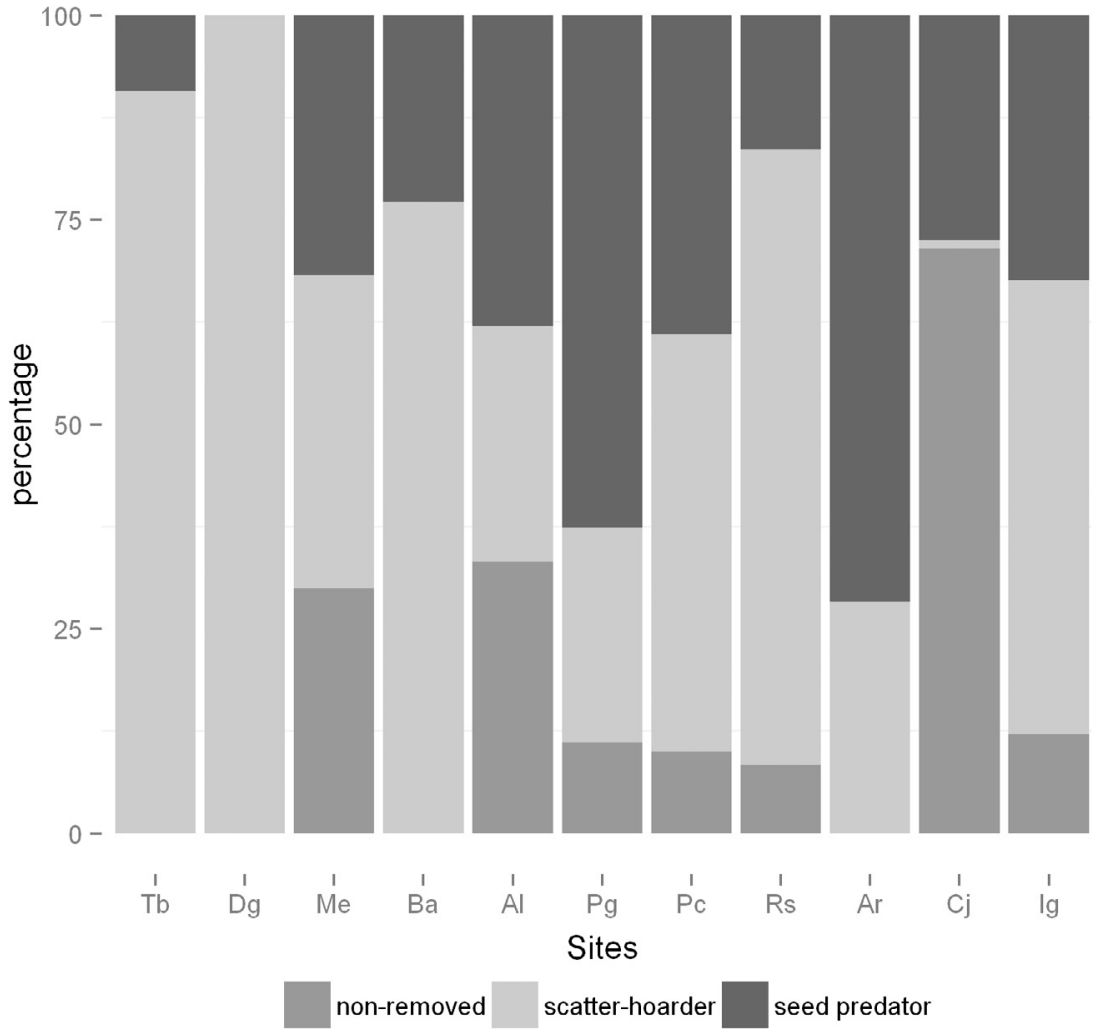

Fig. 2. Percentage of Araucaria angustifolia seed non-removed, removed by scatter-hoarders and seed predators, monitorated through camera trap. Sites are ordered according to patch size. More details about sites see Table S1.
Montana Reserve) exhibited an impoverished native fauna composition, with the presence of the exotic and invasive wild boar (Sus scrofa) (Table S2).

\subsection{Experiments}

(1) Identifying and quantifying seed removers and interactions

We used camera-traps in video function mode (10s, with a 1s delay, Bushnell HD Trophy) to identify and quantify animal species removing the seeds of $A$. angustifolia. The camera-traps were set directly beneath adult Paraná-pine females during seed fall period (austral autumnwinter, March-August 2015), where we set 60 seeds on average in front of the camera. We sampled 3-16 trees per site (11 sites, Table S1), according to forest size and our camera-trap availability. Each camera was placed at minimum $100 \mathrm{~m}$ from each other and let for a period of 17 days on average. In this experiment, we tested hypotheses I, III and IV.

(2) Effects of buried treatment and distance from parent tree to seed survival

We tested whether scatter-hoarding dispersal is necessary for the survival of $A$. angustifolia seeds because many seeds can be dispersed by barochory or occasionally be carried out by non-scatter hoarding frugivores, such as parrots (Tella et al., 2016a) or capuchin monkeys (Brocardo, C.R., pers. obs.). We used eight adult Paraná-pine females at six sites (Table S1), where we placed seeds at six categorical distances along a line up to $30 \mathrm{~m}$ from each tree. At each categorical distance, we placed five seeds above the soil surface separated $20 \mathrm{~cm}$ from each other and three buried seeds (at a depth $5 \mathrm{~cm}$, mimicking scatterhoarding) $20 \mathrm{~cm}$ from each other and $1 \mathrm{~m}$ away from the non-buried seeds. We returned to observe the fate of each group of seed after 15 days. We considered seeds that survived those that were not removed or preyed upon. In this experiment, we tested hypothesis VI.

\section{(3) Paraná-pine recruitment}

With aim of verifying the effects of forest fragmentation and adult density on Paraná-pine recruitment, we established three vegetative plots $(50 \times 50 \mathrm{~m})$ at 9 sites (Table S1). Each plot was placed at a minimum distance of $100 \mathrm{~m}$ from other plots. In these plots, we counted juvenile and adult Paraná-pines. Additionally, because factors other than forest fragmentation and logging may interfere with the recruitment of gymnosperms, such as angiosperm trees (Bond, 1989; Souza, 2007), bamboos (Narukawa and Yamamoto, 2002) and ferns (Coomes et al., 2005), we also measured the dominance of these groups in the plots. For angiosperms, we measured the diameter of all trees with a d.b.h greater than $6.75 \mathrm{~cm}$ and for dominance of bamboo and ferns, we measured the total area $\left(\mathrm{m}^{2}\right)$ occupied by each in the plots. We also consider in our analysis the defaunation level of each site to verify defaunation may interfere in recruitment (Table S2).

In this experiment, we tested the hypotheses II and V.

\subsection{Statistical analyses}

The total seed removal monitored by the camera-traps was analyzed using generalized linear mixed-effects models (family = binomial, link = "logit") using the lme4 package (Bates et al., 2007) in R program ( $R$ Development Core and Team, 2016). The random components of models were the sites and fixed components were the environmental variables (Paraná-pine predominance, distance from forest edge, forest patch size; see Supplemental Material). Non-significant variables were removed in subsequent models to produce as parsimonious models as possible. Afterwards, we separately analyzed the seed removal rate done by scatter-hoarders (agouties, squirrels and plush-crested-jays together) and seed predators (capuchin monkeys, small rodents and ungulates), and also separate models were used for agouties, plushcrested jays and small rodents (grouped together because reliable identification of mice species in the videos was not possible). In these analyses, because the seed removal by one group could interfere with that by another group, we also included proportion of seeds removed in 

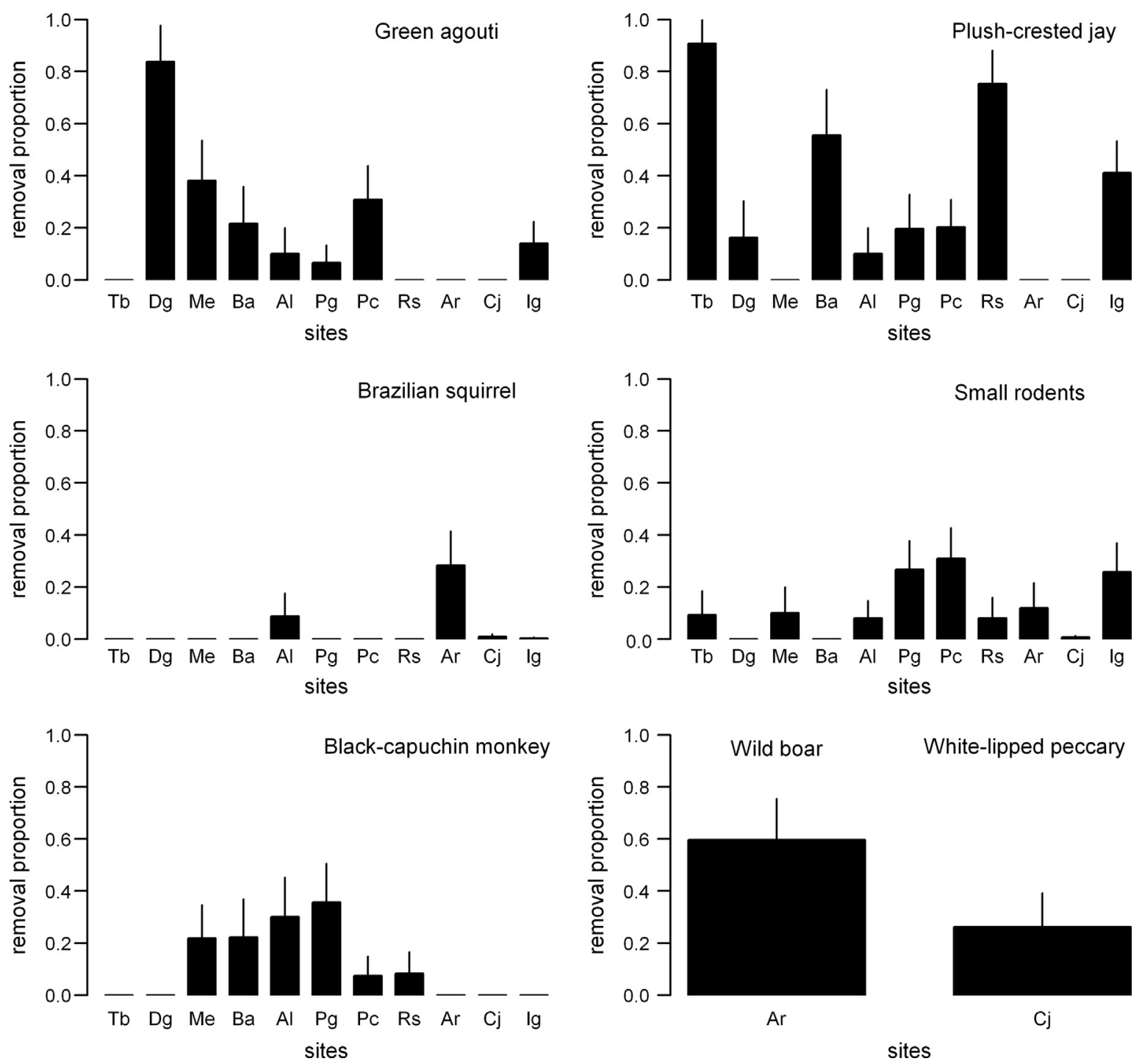

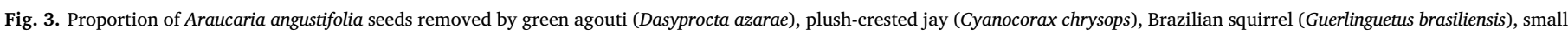

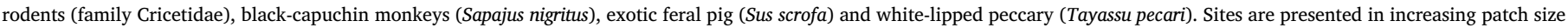
(See Table S1).

the other groups as a fixed factor (Mendes et al., 2015). The best model was chosen according to the AIC with correction for small samples (AICc) (Burnham and Anderson, 2003).

The proportion of surviving seeds from the experiment with buried treatment was analyzed using a generalized linear mixed-effects model (family = binomial, link = "logit"), wherein sites and individual Paraná-pine within sites were combined as random components in the models, and the distance of seeds from Paraná-pines, the treatment (buried vs. non-buried) and forest patch size were used as fixed factors.

For data about Paraná-pine recruitment, we used a generalized linear mixed-effects model (family = Poisson, link = "log"). We used the site as the random component, and fixed components were the number of female Paraná-pine in each plot, forest patch size (logtransformed), percentage of area occupied by angiosperm trees (the total area determined by the sum of areas determined from d.b.h), and the area dominated by ferns (percentage cover in plots), bamboos (percentage cover in plots) and defaunation level (Table S3). In subsequent analyses, we removed non-significant variables with the aim of reducing the explanatory variables and finding a more parsimonious model. The best model was chosen according to $\triangle$ AICc.

All models were confronted with null models, and analyses were preformatted in R program (R Development Core and Team, 2016).

\section{Results}

\subsection{Identifying and quantifying seed removers and interactions}

We found that $83.5 \%$ of the seeds were removed (seeds removed or eaten in place), ranging from $28.5 \%$ to $100 \%$ (Fig. 2, Table S3). When all the seeds were removed, the last seed was removed after 6.5 days on average $(6.1 \pm 1.0$ days in forest fragments, and $7.6 \pm 0.6$ days in continuous sites).

Most seeds were removed by scatter-hoarder species (50.1\% of total available seeds, Fig. 2). Plush-crested jays (C. chrysops) removed $28.4 \%$ of the seeds (ranging from $0 \%$ in some sites to $90 \%$ ), while agouties ( $D$. azarae) removed $18.5 \%(0-84 \%)$ and squirrels (G. brasiliensis) removed only $3.1 \%(0-28 \%)$ (Fig. 3, Table S3). Seed removal by species that act primarily as seed predators corresponded to $33.4 \%$. Small rodents (Cricetidae) performed $13.9 \%$ of the removals $(0-30 \%)$, followed by capuchin-monkeys (Sapajus nigritus) with $11.7 \%(0-36 \%)$ and by exotic and invasive feral pigs (Sus scrofa), which consumed $4.5 \%$ of the total seeds, but preyed upon $59.7 \%$ of the seeds at a single site (Fig. 3). Pacas (Cuniculus paca) and white-lipped peccaries (Tayassu pecari) rarely fed on the seeds ( 1 and $2 \%$ respectively of the total seeds).

Our analyses indicated that the total seed removal was negatively 
Table 1

Results from GLMM analyses for Araucaria angustifolia seed removal. In bold significant responses (All models and value of $\triangle \mathrm{AICc}$ are presented in Table S2).

\begin{tabular}{|c|c|c|c|}
\hline Removal response & $\begin{array}{l}\text { Explanatory variables present in chosen } \\
\text { model }\end{array}$ & z-value & $p$ \\
\hline \multirow[t]{3}{*}{ Total } & Distance from forest edge (log m) & 2.68 & $<0.01$ \\
\hline & Paraná-pine dominance (\%) & -2.76 & $<0.01$ \\
\hline & Forest patch (log ha) & -2.35 & 0.01 \\
\hline \multirow[t]{3}{*}{ All scatter-hoarders } & Seed removal by seed predators & -4.4 & $<0.01$ \\
\hline & Distance from forest edge (log m) & 2.51 & 0.01 \\
\hline & Forest patch (log ha) & -2.22 & 0.02 \\
\hline \multirow[t]{3}{*}{ All seed predators } & Seed removal by scatter-hoarders & -2.4 & 0.01 \\
\hline & Paraná-pine dominance (\%) & -2.74 & $<0.01$ \\
\hline & Distance from forest edge (log m) & 1.59 & 0.11 \\
\hline \multirow[t]{4}{*}{ Agouties } & Seed removal by plush-crested jays & -1.6 & 0.10 \\
\hline & Interaction with seed predators & -2.87 & $<0.01$ \\
\hline & Distance from forest edge (log $\mathrm{m})$ & 1.95 & 0.05 \\
\hline & Forest patch (log ha) & -2.32 & 0.02 \\
\hline \multirow[t]{4}{*}{ Plush-crested jays } & Seed removal by agouties & -2.84 & $<0.01$ \\
\hline & Seed removal by seed predators & -3.35 & $<0.01$ \\
\hline & Distance from forest edge $(\log \mathrm{m})$ & 1.68 & 0.09 \\
\hline & Forest patch (log ha) & -1.01 & 0.12 \\
\hline \multirow[t]{3}{*}{ Small rodents } & Seed removal by scatter-hoarders & -2.05 & 0.03 \\
\hline & Distance from forest edge $(\log \mathrm{m})$ & 2.55 & 0.01 \\
\hline & Paraná-pine dominance (\%) & -1.87 & 0.06 \\
\hline
\end{tabular}

affected by forest patch size and Paraná-pine tree dominance, and was positively affected by the distance from forest edge (Table 1). Seeds have more chances to be removed in areas with low Paraná-pine dominance, in small fragments and in locations more distant from forest edges.

The proportion of seed removal performed by scatter-hoarder species was negatively affected by the seed removal performed by seed predators and forest patch size, and was positively affected by the distance to the forest edge. Seed removal by predators was negatively affected by scatter-hoarder seed removal and Paraná-pine dominance. Seed removal performed by agouties was negatively affected by the forest patch size and the seed removal performed by seed predators, and was positively affected by the distance to forest edge. Seed removal by plush-crested jays was negatively affected by the removal performed by both agouties and seed predators. Finally, the seed removal by nocturnal small rodents was positively affected by increasing distances from the forest edge and negatively affected by removal performed by scatter-hoarders (the value of the best model for each analysis is presented in Table 1, even though other models may have the same inference power $\triangle \mathrm{AICc} \leq 2.0$, the significance of explanatory variables did not change; see Table S3).

\subsection{Effects of buried treatment and distance from the parent tree on seed survival}

Cached seeds had on average a $46 \% \pm 2 \%$ (mean \pm se) rate of survival, while only $1.8 \% \pm 0.01 \%$ of seeds left on the surface of soil remained intact after 15 days of exposure. Our analysis found a significant impact on of survival according to treatment (soil surface; zvalue $=-8.78, p<.001$ ), whereas the distance of seeds from fruiting-trees (z-value $=0.58, \mathrm{p}=.56$ ) and forest patch size $(\mathrm{z}$ value $=1.54, p=0.12$ ) were not significant. Thus, the results showed that the buried treatment provided by scatter-hoarders increased seed survival 25-fold, independent of the distance from female-trees.

\subsection{Paraná-pine recruitment}

Our control site for the recruitment analysis (Iguaçu National Park site number 12) exhibited the largest recruitment, with a mean of $382.6 \pm 122.8$ juveniles/ha (mean \pm se), while forest fragments exhibited a mean recruitment that was 4 -fold lower $(86.5 \pm 11.1$, ranging from 6 to 125 juveniles/ha on average) (Fig. 4). Adult Paraná-pine density was also higher in the continuous site, with $52 \pm 18$ adults/ha, whereas forest fragments had a mean of $19.3 \pm 2.9$ adults/ha (ranging from 6.6 to 34.6 adults/ha on average) (Fig. 4). Only the number of Paraná-pine females $(z$-value $=6.69, p<.001)$ and forest patch size (z-value $=2.36, p=.01$ ) were significant explanatory variables, and both were positively related to the total number of juveniles in the plots (Table S3).

\section{Discussion}

Our results show that human interferences in Araucaria moist forest have had negative effects on the ecology of A. angustifolia, due to changes in the seed predator communities and the natural availability of seeds, which in turn diminish seed survival and recruitment, indicating that the seed stage may be the most critical phase in the Paraná-pine lifecycle.

In places with higher predominance of Paraná-pines, we observed increased chances for seeds to escape predation and higher rates of recruitment, as we had expected (hypothesis I). Thus, the formation of large and dense groves by this conifer, a characteristic of pristine Araucaria moist forests, probably represents an attempt to satiate its seed predators and dispersers. Therefore, forest fragments that had experienced harvesting of Paraná-pine trees tended to be more affected and present higher rates of seed removal. High seed abundance is a characteristic necessary for the success of scatter-hoarding seed dispersal (Forget, 1990; Vander Wall, 2002; Jansen et al., 2004; Theimer, 2005). The high seed abundance in dense groves may sufficiently satiate dispersers, resulting in superior recruitment rates in these areas (Forget, 1990; Forget, 1992; Jansen et al., 2004; Vieira et al., 2011). Our recruitment results related to female tree numbers corroborate this view (hypothesis II), this areas probably produce more seeds, and thus diminish the proportion of preyed seeds. Additionally, although, Paraná-pine apparently does not present masting seed production, the seed crop varies along the years (Souza et al., 2010), thus future researches must investigate if interaction patterns and seedling recruitment may change according the fluctuation of seed production. For example, for Araucaria araucana the proportion of preyed seeds is lesser
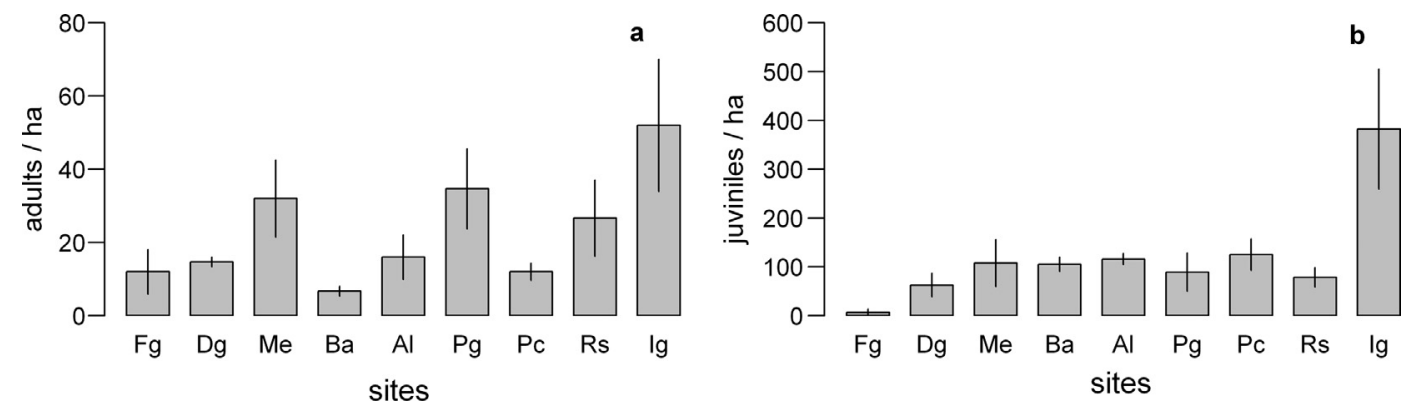

Fig. 4. Adult and juveniles density of Araucaria angustifolia in nine sites where we measure recruitment. Sites are ordered according to patch size (See Table S1). 
in years of high seed production (masting years), with positive effects on seedling recruitment (Shepherd et al., 2008; Sanguinetti and Kitzberger, 2009; Sanguinetti and Kitzberger, 2010).

Forest fragments presented high seed removal (hypothesis III), which may represent a high seed predation leading to a lower recruitment in forest fragments than observed in control site (hypothesis V). Although, we did not find a significant response in the interaction between small rodents and Paraná-pine seeds and forest patch size, as we had expected (hypothesis IV). However, in the same way that change in seed production along the years may interfere in seed removal patterns, the fluctuation on granivore populations also may change the proportion of their interactions. A previous study have found difference in Paraná-pine seed removal done by small rodents in two different years, which may related to alteration in rodent density (Iob and Vieira, 2008).

Fragmentation appears to benefit the seed interaction with scatterhoarders, mainly agouties in some fragments, which led us to reject the sixth hypothesis, in contrast with other works in Atlantic forest (Galetti et al., 2006; Iob and Vieira, 2008; Brum et al., 2010; Galetti et al., 2015). Agouties may respond positively to forest fragmentation because of competitive and predator releases (Jorge, 2008), even increasing seed caching in some sites, where they are not preferred game species (Kurten, 2013). Constant interactions with scatter-hoarders, even in small forest fragments, might have a cascade effect on small rodent interactions. Indeed, presence of larger species may limit small rodent predation on seeds (Galetti et al., 2015).

One advantage of maintaining a high level of interaction with scatter-hoarders is the functional service that they provide: seed dispersal via individual caching. Our study demonstrated that scatterhoarders were important to $A$. angustifolia regeneration because the cached treatment was more important to seed survival than seed dispersal distance from mother trees (hypothesis VII). The positive effect of scatter-hoarders on seed survival has been observed in diverse plant genera (Forget, 1990; Gómez, 2004; Jansen et al., 2004; Myczko et al., 2014), despite the fact that relatively few seeds can survive the recovery did by scatter-hoarders themselves (Jansen et al., 2004; Haugaasen et al., 2010), a fact also observed for A. angustifolia (Ribeiro and Vieira, 2014, 2016). Thereby reduction in resources availability, such as caused by forest fragmentation, may decrease the seed caching and survival of cached seeds (Theimer, 2005). Jorge and Howe (2009), for example, found higher seed predation in small Amazonian forest fragments than in large forest fragments or continuous forest sites, and the seeds hoarded by rodents also decreased. In our study, seed removal rates by scatter-hoarders remain high in forest fragments, although Paraná-pine recruitment decreasing in mean fourfold in these sites in relation to control site, suggesting a scenario with low seed dispersal effectiveness in forest fragments in contrast with the continuous forests. However, specific studies are required to measure how much $A$. angustifolia seed dispersal effectiveness by scatter-hoarders is affected by forest fragmentation.

Forest fragments also may lead others species to increase their impacts on seed predation. For example, black-capuchin monkeys, species that is not hunted in Araucaria moist forests, exhibited a higher impact on seed predation in forest fragments $(17 \%$ on average considering only forest fragments), while they were not recorded removing seeds in continuous sites. Additionally, capuchin-monkeys may have a significant impact when directly feeding on seeds in female Paraná-pine trees, damaging more than half of all seeds produced in a year (Pagno et al., 2015).

Nevertheless, no seed predator (excluding scatter-hoarders) presented as high a secondary seed removal in a site as did the exotic boar. This invasive species was responsible for killing $59.7 \%$ of the seeds at a single site, the only continuous area where all seeds were removed. The high seed predation by the wild boar is extremely worrying, because similar native species, such as the white-lipped peccary and collaredpeccary (Pecari tajacu), did not have the same impact. White-lipped peccaries were only recorded preying on seeds at one site, where they consumed $26.2 \%$ of the seeds, less than half of that consumed by wild boar. Currently, wild boar (and other forms of feral pigs) are established in most parts of Araucaria moist forest in Brazil and their population has increased and expanded to new areas (Fig. S1) (Pedrosa et al., 2015; da Rosa et al., 2017), which may affect $A$. angustifolia recruitment. In the Chilean and Argentinean Araucaria-Nothofagus temperate forests, the introduction of wild boar has caused a considerable increase in seed predation and a reduction in the seedling recruitment of $A$. araucana (Sanguinetti and Kitzberger, 2010; Tella et al., 2016b).

Seed dispersal and survival are critical stages in the plant life-cycle and will pose a challenge for the persistence of many animal-dispersed plants in the Anthropocene (Galetti et al., 2015; Mendes et al., 2015; Pérez-Méndez et al., 2016; Rosin and Poulsen, 2016; Tella et al., 2016b). Our results highlight the effects of forest fragmentation, selective logging and animal community changes on seed predation and the recruitment of a relictual tree species. Today, most Araucaria moist forest is formed by fragments up to 100 ha (90\%, Ribeiro et al., 2009), indicating that few sites may be able to satiate their seed predators. In addition to animal pressure, Paraná-pine seeds are collected for human consume, which may inhibit the regeneration of this species (Souza, 2007). Controlling forest degradation, increasing the protection and recuperation of forest cover, and eradicating the invasive wild boar where possible, are all necessary measures for increasing seed survival rates and consequently recruitment of this relictual species.

\section{Acknowledgements}

We would to thank the Instituto Chico Mendes de Conservação da Biodiversidade (ICMBio), Instituto Ambiental do Paraná (IAP), Instituto Florestal de São Paulo (IF), Environmental secretary of Cascavel, and the directors of protected areas for authorizing this research. We also thank to the land owners for allowing us access to forest fragments located on private property. We are very grateful to our trainees and our field assistants (Robson Machado and Mauro Costa) for their indispensable field work assistance. We thank Ana Tereza B. Guimarães for helping with our statistical questions and Pedro Jordano for his suggestions. We thank Karina Emer and Carolina de Carvalho da Silva for their review and kind suggestions to improving this manuscript. CRB and MG received fellowships from Conselho Nacional de Desenvolvimento Científico e Tecnológico (CNPq). FP received a fellowship from the Fundação de Amparo à Pesquisa do Estado de São Paulo (FAPESP).

\section{Appendix A. Supplementary material}

Supplementary data associated with this article can be found, in the online version, at http://dx.doi.org/10.1016/j.foreco.2017.09.046.

\section{References}

Bates, D., Sarkar, D., Douglas Bates, M., 2007. The lme4 Package Title Linear mixedeffects models using S4 classes.

Bond, W.J., 1989. The tortoise and the hare: ecology of angiosperm dominance and gymnosperm persistence. Biol. J. Linn. Soc. 36, 227-249. http://dx.doi.org/10.1111/ j.1095-8312.1989.tb00492.x.

Brocardo, C.R., Cândido Júnior, J.F., 2012. Persistência de mamíferos de médio e grande porte em fragmentos de floresta ombrófila mista no estado do Paraná, Brasil. Rev. Árvore 36, 301-310. http://dx.doi.org/10.1590/S0100-67622012000200011.

Brocardo, C.R., da Silva, M.X., da Delgado, L.E.S., Galetti, M., 2017. White-lipped peccaries are recorded at Iguaçu National Park after 20 years. Mammalia 81, 168-171. http://dx.doi.org/10.1515/mammalia-2016-0049.

Brum, F., Duarte, L., Hartz, S., 2010. Seed removal patterns by vertebrates in different successional stages of Araucaria forest advancing over southern Brazilian grasslands. Commun. Ecol. 11, 35-40. http://dx.doi.org/10.1556/ComEc.11.2010.1.6.

Burnham, K.P., Anderson, D.R., 2003. Model Selection and Multimodel Inference: A Practical Information-Theoretic Approach. Springer.

Butchart, S.H.M., Walpole, M., Collen, B., van Strien, A., Scharlemann, J.P.W., Almond, R.E.A., Baillie, J.E.M., Bomhard, B., Brown, C., Bruno, J., Carpenter, K.E., Carr, G.M., Chanson, J., Chenery, A.M., Csirke, J., Davidson, N.C., Dentener, F., Foster, M., Galli, A., Galloway, J.N., Genovesi, P., Gregory, R.D., Hockings, M., Kapos, V., Lamarque, J.-F., Leverington, F., Loh, J., McGeoch, M.A., McRae, L., Minasyan, A., Morcillo, M.H., Oldfield, T.E.E., Pauly, D., Quader, S., Revenga, C., Sauer, J.R., Skolnik, B., Spear, D., Stanwell-Smith, D., Stuart, S.N., Symes, A., Tierney, M., Tyrrell, T.D., Vie, J.-C., Watson, R., 2010. Global biodiversity: indicators of recent declines. Science 
328, 1164-1168, http://dx doi.org/10.1126/science 1187512.

Castella, P., de Britez, R., 2004. A floresta com araucária no Paraná: conservação e diagnóstico dos remanescentes florestais.

Connell, J.H., 1978. Diversity in tropical rain forests and coral reefs. Sci. New Ser. 199, 1302-1310.

Coomes, D.A., Allen, R.B., Bentley, W.A., Burrows, L.E., Canham, C.D., Fagan, L., Forsyth, D.M., Gaxiola-Alcantar, A., Parfitt, R.L., Ruscoe, W.A., Wardle, D.A., Wilson, D.J., Wright, E.F., 2005. The hare, the tortoise and the crocodile: the ecology of angiosperm dominance, conifer persistence and fern filtering. J. Ecol. 93, 918-935. http:// dx.doi.org/10.1111/j.1365-2745.2005.01012.x.

Cordeiro, N.J., Ndangalasi, H.J., McEntee, J.P., Howe, H.F., 2009. Disperser limitation and recruitment of an endemic African tree in a fragmented landscape. Ecology 90, 1030-1041. http://dx.doi.org/10.1890/07-1208.1.

da Rosa, C.A., de Almeida Curi, N.H., Puertas, F., Passamani, M., 2017. Alien terrestrial mammals in Brazil: current status and management. Biol. Invasions 19, 2101-2123. http://dx.doi.org/10.1007/s10530-017-1423-3.

Dirzo, R., Young, H.S., Galetti, M., Ceballos, G., Isaac, N.J.B., Collen, B., 2014. Defaunation in the anthropocene. Science 345, 401-406. http://dx.doi.org/10.1126/ science. 1251817.

Estes, J.A., Terborgh, J., Brashares, J.S., Power, M.E., Berger, J., Bond, W.J., Carpenter, S.R., Essington, T.E., Holt, R.D., Jackson, J.B.C., Marquis, R.J., Oksanen, L., Oksanen, T., Paine, R.T., Pikitch, E.K., Ripple, W.J., Sandin, S.A., Scheffer, M., Schoener, T.W., Shurin, J.B., Sinclair, A.R.E., Soulé, M.E., Virtanen, R., Wardle, D.A., 2011. Trophic downgrading of planet earth. Science 333, 301-306. http://dx.doi.org/10.1126/ science. 1205106

Forget, P.-M., 1992. Seed removal and seed fate in Gustavia superba (Lecythidaceae). Biotropica 24, 408-414. http://dx.doi.org/10.2307/2388611.

Forget, P.-M., 1990. Seed-dispersal of Vouacapoua americana (Caesalpiniaceae) by caviomorph rodents in French Guiana. J. Trop. Ecol. http://dx.doi.org/10.1017/ S0266467400004867.

Galetti, M., Bovendorp, R.S., Guevara, R., 2015. Defaunation of large mammals leads to an increase in seed predation in the Atlantic forests. Glob. Ecol. Conserv. 3, 824-830. http://dx.doi.org/10.1016/j.gecco.2015.04.008.

Galetti, M., Dirzo, R., 2013. Ecological and evolutionary consequences of living in a defaunated world. Biol. Conserv. 163, 1-6. http://dx.doi.org/10.1016/j.biocon.2013. 04.020.

Galetti, M., Donatti, C.I., Pires, A.S., Guimarães, P.R., Jordano, P., 2006. Seed survival and dispersal of an endemic Atlantic forest palm: the combined effects of defaunation and forest fragmentation, in: Botanical Journal of the Linnean Society. Springer, New York, pp. 141-149. 10.1111/j.1095-8339.2006.00529.x.

Galetti, M., Guevara, R., Cortes, M.C., Fadini, R., Von Matter, S., Leite, A.B., Labecca, F., Ribeiro, T., Carvalho, C.S., Collevatti, R.G., Pires, M.M., Guimaraes, P.R., Brancalion, P.H., Ribeiro, M.C., Jordano, P., 2013. Functional extinction of birds drives rapid evolutionary changes in seed size. Science 340, 1086-1090. http://dx.doi.org/10. 1126 /science.1233774.

Gómez, J.M., 2004. Importance of microhabitat and acorn burial on Quercus ilex early recruitment: non-additive effects on multiple demographic processes. Plant Ecol. (formerly Veg.) 172, 287-297. http://dx.doi.org/10.1023/B:VEGE.0000026327. 60991.f9.

Haugaasen, J.M.T., Haugaasen, T., Peres, C.A., Gribel, R., Wegge, P., 2010. Seed dispersal of the Brazil nut tree (Bertholletia excelsa) by scatter-hoarding rodents in a central Amazonian forest. J. Trop. Ecol. 26, 251-262. http://dx.doi.org/10.1017/ S0266467410000027.

Iob, G., Vieira, E.M., 2008. Seed predation of Araucaria angustifolia (Araucariaceae) in the Brazilian Araucaria Forest: influence of deposition site and comparative role of small and "large" mammals. Plant Ecol. 198, 185-196. http://dx.doi.org/10.1007/s11258007-9394-6.

Jansen, P.A., Bongers, F., Hemerik, L., 2004. Seed mass and mast seeding enhance dispersal by a neotropical scatter-hoarding rodent. Ecol. Monogr. 74, 569-589. http:// dx.doi.org/10.1890/03-4042.

Janzen, D.H., 1971. Seed predation by animals. Annu. Rev. Ecol. Syst. 2, 465-492. http:// dx.doi.org/10.1146/annurev.es.02.110171.002341.

Jorge, M.L.S.P., 2008. Effects of forest fragmentation on two sister genera of Amazonian rodents (Myoprocta acouchy and Dasyprocta leporina). Biol. Conserv. 141, 617-623. http://dx.doi.org/10.1016/j.biocon.2007.11.013.

Jorge, M.L.S.P., Howe, H.F., 2009. Can forest fragmentation disrupt a conditional mutualism? A case from central Amazon. Oecologia 161, 709-718. http://dx.doi.org/10. 1007/s00442-009-1417-7.

Kershaw, P., Wagstaff, B., 2001. The southern conifer family araucariaceae: history, status, and value for paleoenvironmental reconstruction. Annu. Rev. Ecol. Syst. 32, 397-414. http://dx.doi.org/10.1146/annurev.ecolsys.32.081501.114059.

Kurten, E.L., 2013. Cascading effects of contemporaneous defaunation on tropical forest communities. Biol. Conserv. 163, 22-32. http://dx.doi.org/10.1016/j.biocon.2013. 04.025 .

Kurten, E.L., Wright, S.J., Carson, W.P., 2015. Hunting alters seedling functional trait composition in a Neotropical forest. Ecology 96, 1923-1932. http://dx.doi.org/10 1890/14-1735.1.

Mendes, C.P., Ribeiro, M.C., Galetti, M., 2015. Patch size, shape and edge distance influence seed predation on a palm species in the Atlantic forest. Ecography (Cop.) 39, 465-475. http://dx.doi.org/10.1111/ecog.01592.

Myczko, Ł., Dylewski, Ł., Zduniak, P., Sparks, T.H., Tryjanowski, P., 2014. Predation and dispersal of acorns by European Jay (Garrulus glandarius) differs between a native (Pedunculate Oak Quercus robur) and an introduced oak species (Northern Red Oak Quercus rubra) in Europe. For. Ecol. Manage. 331, 35-39. http://dx.doi.org/10. 1016/j.foreco.2014.07.027.

Narukawa, Y., Yamamoto, S., 2002. Effects of dwarf bamboo (Sasa sp.) and forest floor microsites on conifer seedling recruitment in a subalpine forest, Japan. For. Ecol.
Manage. 163, 61-70. http://dx.doi.org/10.1016/S0378-1127(01)00527-8.

Nathan, R., Muller-Landau, H.C., 2000. Spatial patterns of seed dispersal, their determinants and consequences for recruitment. Trends Ecol. Evol. 15, 278-285. http://dx. doi.org/10.1016/S0169-5347(00)01874-7.

Neuschulz, E.L., Mueller, T., Schleuning, M., Böhning-Gaese, K., 2016. Pollination and seed dispersal are the most threatened processes of plant regeneration. Sci. Rep. 6, 29839. http://dx.doi.org/10.1038/srep29839.

Pagno, L., Cândido Jr, J.F., Brocardo, C.R., 2015. Seed predation of Araucaria angustifolia by Sapajus nigritus. Neotrop. Primates 22, 1-6.

Paludo, G.F., Lauterjung, M.B., dos Reis, M.S., Mantovani, A., 2016. Inferring population trends of Araucaria angustifolia (Araucariaceae) using a transition matrix model in an old-growth forest. South. For. J. For. Sci. 78, 137-143. http://dx.doi.org/10.2989/ 20702620.2015.1136506.

Pedrosa, F., Salerno, R., Vinicius, F., Padilha, B., Galetti, M., 2015. Current distribution of invasive feral pigs in Brazil: economic impacts and ecological uncertainty. 10.1016/j. ncon.2015.04.005.

Pérez-Méndez, N., Jordano, P., García, C., Valido, A., 2016. The signatures of Anthropocene defaunation: cascading effects of the seed dispersal collapse. Sci. Rep. 6, 24820. http://dx.doi.org/10.1038/srep24820.

R Development Core, Team, 2016. A Language and Environment for Statistical Computing. R Foundation for Statistical Computing, Viena.

Ribeiro, J.F., Vieira, E.M., 2016. Microhabitat selection for caching and use of potential landmarks for seed recovery by a neotropical rodent. J. Zool. 300, 274-280. http:// dx.doi.org/10.1111/jzo.12380.

Ribeiro, J.F., Vieira, E.M., 2014. Interactions between a seed-eating neotropical rodent, the Azara's agouti (Dasyprocta azarae), and the Brazilian "pine" Araucaria angustifolia Austral Ecol. 39, 279-287. http://dx.doi.org/10.1111/aec.12077.

Ribeiro, M.C., Metzger, J.P., Martensen, A.C., Ponzoni, F.J., Hirota, M.M., 2009. The Brazilian Atlantic Forest: How much is left, and how is the remaining forest distributed? Implications for conservation. Biol. Conserv. 142, 1141-1153. http://dx doi.org/10.1016/j.biocon.2009.02.021.

Rosin, C., Poulsen, J.R., 2016. Hunting-induced defaunation drives increased seed predation and decreased seedling establishment of commercially important tree species in an Afrotropical forest. For. Ecol. Manage. 382, 206-213. http://dx.doi.org/10. 1016/j.foreco.2016.10.016.

Sanderson, E.W., Jaiteh, M., Levy, M.A., Redford, K.H., Wannebo, A.V., Woolmer, G., 2002. The human footprint and the last of the wild. Bioscience 52, 891. http://dx.doi org/10.1641/0006-3568(2002) 052[0891:THFATL]2.0.CO;2.

Sanguinetti, J., Kitzberger, T., 2010. Factors controlling seed predation by rodents and non-native Sus scrofa in Araucaria araucana forests: potential effects on seedling establishment. Biol. Invas. 12, 689-706. http://dx.doi.org/10.1007/s10530-0099474-8.

Sanguinetti, J., Kitzberger, T., 2009. Efectos de la producción de semillas y la heterogeneidad vegetal sobre la supervivencia de semillas y el patrón espacio-temporal de establecimiento de plántulas en Araucaria araucana. Rev. Chil. Hist. Nat. 82, 319-335. http://dx.doi.org/10.4067/S0716-078X2009000300001.

Schupp, E.W., Jordano, P., Gómez, J.M., 2010. Seed dispersal effectiveness revisited: a conceptual review. New Phytol. 188, 333-353. http://dx.doi.org/10.1111/j.14698137.2010.03402.x.

Shepherd, J.D., Ditgen, R.S., Sanguinetti, J., 2008. Araucaria araucana and the Austral parakeet: pre-dispersal seed predation on a masting species. Hist. Nat. 81, 395-401.

Souza, A.F., 2007. Ecological interpretation of multiple population size structures in trees: the case of Araucaria angustifolia in South America. Austr. Ecol. 32, 524-533. http:// dx.doi.org/10.1111/j.1442-9993.2007.01724.x.

Souza, A.F., Uarte de Matos, D., Forgiarini, C., Martinez, J., 2010. Seed crop size variation in the dominant South American conifer Araucaria angustifolia. Acta Oecol. 36, 126-134. http://dx.doi.org/10.1016/j.actao.2009.11.001.

Tella, J.L., Dénes, F.V., Zulian, V., Prestes, N.P., Martínez, J., Blanco, G., Hiraldo, F., 2016a. Endangered plant-parrot mutualisms: seed tolerance to predation makes parrots pervasive dispersers of the Parana pine. Sci. Rep. 6, 31709. http://dx.doi.org/ $10.1038 /$ srep31709.

Tella, J.L., Lambertucci, S.A., Speziale, K.L., Hiraldo, F., 2016b. Large-scale impacts of multiple co-occurring invaders on monkey puzzle forest regeneration, native seed predators and their ecological interactions. Glob. Ecol. Conserv. 6, 1-15. http://dx. doi.org/10.1016/j.gecco.2016.01.001.

Theimer, T.C., 2005. Rodent scatterhoarders as conditional mutualists. In: Forget, P.-M., Lambert, J.E., Hulme, P.E., Vander Wall, S.B. (Eds.), Seed Fate: Predation, Dispersal, and Seedling Establishment. pp. 284-295. 10.1079/9780851998060.0283.

Thomas, P., 2013. Araucaria angustifolia. The IUCN Red List of Threatened Species 2013: e.T32975A2829141. 10.2305/IUCN.UK.2013-1.RLTS.T32975A2829141.en.

Tylianakis, J.M., Didham, R.K., Bascompte, J., Wardle, D.A., 2008. Global change and species interactions in terrestrial ecosystems. Ecol. Lett. 11, 1351-1363. http://dx. doi.org/10.1111/j.1461-0248.2008.01250.x

Vander Wall, S.B., 2002. Masting in animal-dispersed pines facilitates seed dispersal. Ecology 83, 3508-3516. http://dx.doi.org/10.1890/00129658(2002) 083[3508:MIADPF]2.0.CO;2.

Vieira, E.M., Ribeiro, J.F., Iob, G., 2011. Seed predation of Araucaria anoustifolia (Araucariaceae) by small rodents in two areas with contrasting seed densities in the Brazilian Araucaria forest. J. Nat. Hist. 45, 843-854. http://dx.doi.org/10.1080/ 00222933.2010 .536265$.

Wright, S.J., Zeballos, H., Domínguez, I., Gallardo, M.M., Moreno, M.C., Ibáñez, R., 2000 Poachers Alter Mammal Abundance, Seed Dispersal, and Seed Predation in a Neotropical Forest. Conserv. Biol. 14, 227-239. http://dx.doi.org/10.1046/j.1523 1739.2000.98333.x.

Young, H.S., McCauley, D.J., Galetti, M., Dirzo, R., 2016. Patterns, causes, and consequences of anthropocene defaunation. Annu. Rev. Ecol. Evol. Syst. 47, 333-358. http://dx.doi.org/10.1146/annurev-ecolsys-112414-054142. 